\title{
Simvastatin treatment varies the radiation response of human breast cells in 2D or 3D culture
}

\author{
Katrin Manda ${ }^{1}$ (D) $\cdot$ Dajana Juerß $^{1} \cdot$ Paul Fischer $^{1} \cdot$ Annemarie Schröder $^{1}$ (D) $\cdot$ Annelie Koenen ${ }^{1} \cdot$ Guido Hildebrandt ${ }^{1}$
}

Received: 5 June 2020 / Accepted: 6 December 2020 / Published online: 11 December 2020

(C) The Author(s) 2020

\section{Summary}

Background Statins inhibit the cholesterol biosynthesis and are used as cholesterol-lowering agents in fat-metabolism disorders. Furthermore, several studies state that statins have supportive functions in breast cancer treatment. Therefore, simvastatin (SVA) as a potential radiosensitizer should be investigated on the basis of human breast cells. Methods First, an optimal concentration of SVA for normal (MCF10A) and cancer (MCF-7) cells was identified via growth and cytotoxicity assays that, according to the definition of a radiosensitizer in the narrower sense, enhances the effect of radiation therapy but has no cytotoxic effect. Next, in combination with radiation SVA's influence on DNA repair capacity and clonogenic survival in 2D and 3D was determined. Furthermore cell cycle distribution, expression of survivin and connective tissue growth factor (CTGF) as well as ERK1 map kinase were analysed. Results $1 \mu \mathrm{M}$ SVA was identified as highest concentration without an influence on cell growth and cytotoxicity and was used for further analyses. In terms of early and residual $\gamma \mathrm{H} 2 \mathrm{AX}$-foci, SVA affected the number of foci in both cell lines with or without irradiation. Different radiation responses were detected in 2D and 3D culture conditions. During the 2D cultivation, a radiosensitizing effect within the clonogenic survival was observable, but not in 3D. Conclusion The present study suggests that SVA may have potential for radiosensitization. Therefore, it is important to further investigate the role of SVA in relation to the extent of radiosensitization and how it could be used to positively influence the therapy of breast cancer or other entities.

Keywords MCF-7 · MCF10A $\cdot$ Simvastatin $\cdot$ Radiation · 3D

Katrin Manda and Dajana Juerß contributed equally to this work.

\section{Katrin Manda}

katrin.manda@uni-rostock.de

Dajana Juerß

dajana.buttler@web.de

Paul Fischer

paul.fischer@uni-rostock.de

Annemarie Schröder

annemarie.schroeder@uni-rostock.de

Annelie Koenen

annelie.koenen@uni-rostock.de

Guido Hildebrandt

guido.hildebrandt@uni-rostock.de

1 Department of Radiotherapy and Radiation Oncology, University Medical Center Rostock, Suedring 75, 18059 Rostock, Germany

\section{Introduction}

Simvastatin (SVA) belongs to the group of statins which act as competitive inhibitors of the 3-hydroxy-3-methylglutaryl coenzyme A (HMG-CoA)-reductase and are used as cholesterollowering drugs. In this function, statins directly inhibit the formation of mevalonate from HMG-CoA and thus also the biosynthesis of cholesterol [1].

But next to its cholesterol-lowering effect, several studies mention statins' preventive and supportive functions before, during, and after cancer treatment [2-5]. In breast cancer patients for example, decreased recurrence rates relating to the use of statins were described [6,7]. Beckwitt et al. (2018) have summarized the potential of statins to reduce the progression and mortality of breast cancer; they have supported the use of statins as a secondary prevention measure [8]. Within the scope of preoperative treatment with statins, a reduced tumour cell proliferation rate in breast cancer patient samples, 
measured by the KI67-expression, was observed [9]. Owing to its beneficial efforts for breast cancer patients, it was supported as a component of adjuvant therapy [10]. But, in fact, not all tumour entities are equally sensitive to statins, there are also studies that found no beneficial effect of them in a colon cancer cohort [11] and for triple negative breast cancer patients [12].

While exploring the beneficial effort of statins, experimental studies have shown a sensitizing effect on tumour cells, either in combination with chemotherapeutics $[13,14]$ or with radiation treatment $[15,16]$. A recently published study reveals that a combined treatment of SVA and a Vitamin E analogue led to an enhancement of radiation protection in mice [17]. Two other experimental studies have already proven the radioprotective effect of a further statin, lovastatin. First, it was observed in vivo that a reduced pro-inflammatory radiation response after lovastatin treatment caused a decreased level of radiationinduced normal tissue damage [18]. Second, incubation with lovastatin resulted in creating some kind of protection for endothelial cells [19] and combined with doxorubicin of keratinocytes [20] against the ionizing radiation (IR)-induced cell death.

But on what mechanisms is the supportive effect of statins based? It have been shown that SVA alone or SVA combined with a Vitamin $\mathrm{E}$ analogue supports the induction of an anticoagulant with radio-protective efficacy [17]. Another supportive effect could be that SVA can elicit an inhibition of the ATP-binding cassette $(\mathrm{ABC})$ transporters like ABCB1 (P-glycoprotein), which can promote drug-resistance by repressing chemotherapeutics so that drug treatment on different tumour cell lines could be improved through application of SVA. [21]. It could be assumed that as basic mechanisms, for example, posttranslational and epigenetic modifications would ensure the effect of statins. A downregulation of the expression of DNMT1, a key player in epigenetic regulation, and further epigenetic changes, such as downregulation of histone deacetylases, on different tumour cells caused by SVA treatment have been detected [22].

Until now, there has been less experimental data on the effect of statins on normal human cells of the breast. While in epidemiological studies statins showed a beneficial effort for patients, as described above, it could be assumed that the resultant radiation protection is one mechanism of the positive effect of statins.

Owing to the large use of SVA, the present study focuses on the investigation of the potentially radioprotective effect of the drug on normal cells and the possible radiosensitizing effect on cancer cells, both in the human breast. Additionally, it has been tested whether the effect of SVA on the cellular radiation response differs between 2D and 3D cell-culturing conditions. In 3D cell culture conditions, cells behave more similar to the in vivo situation than in the 2D cell culture conditions. Moreover, it is known that the radiation response differs between 2D and 3D cell cultures [23].

To verify the potential of SVA as a possible supporting drug with less side effects in radiotherapy, our study investigates more closely the influence of SVA on cancer and normal cells of the human breast and their radiation responses.

\section{Methods}

\section{Cell culture and simvastatin treatment}

In the present study, MCF10A (provided by Prof. Kevin Prise, Queen's University Belfast, Ireland), a spontaneously transformed cell line from normal human breast epithelial cells [24], and MCF-7 (ATCC; HTB-22 ${ }^{\mathrm{TM}}$ ), a breast cancer cell line, were used. The MCF10A cells were cultivated using Dulbecco's modified Eagle medium/F12 (DMEM/F12, Gibco/Life Technologies, Darmstadt, Germany) supplemented with $0.01 \%$ cholera toxin, $0.1 \%$ insulin, $0.05 \%$ hydrocortisone and $1 \%$ penicillin/streptomycin (all Sigma Aldrich, Hamburg, Germany), $0.02 \%$ epidermal growth factor (EGF; Gibco/Life Technologies), and 5\% horse serum (Fisher Scientific, Schwerte, Germany). The MCF-7 and MDA-MB231 cells were cultured in DMEM media (Lonza/Biozym, Basel, Switzerland) supplemented with $10 \%$ foetal calf serum (Biochrom GmbH, Berlin, Germany) and 1\% penicillin/ streptomycin (Sigma-Aldrich Chemie GmbH, Taufkirchen, Germany). All three cell lines were cultivated under 5\% $\mathrm{CO}_{2}$ at $37{ }^{\circ} \mathrm{C}$ and passaged two times a week using a $0.05 \%$ trypsin/EDTA solution (Biochrom GmbH, Berlin, Germany).

Simvastatin (SVA; Sigma Aldrich) was solved in DMSO (Merck, Darmstadt, Germany) and added to the cells in different concentrations $(0.05 \mu \mathrm{M}, 0.1 \mu \mathrm{M}, 0.5 \mu \mathrm{M}, 1 \mu \mathrm{M}$, $3 \mu \mathrm{M})$. A control for DMSO, as a solvent, was also carried out relating to the DMSO level in the highest level of SVA application. SVA was always added $24 \mathrm{~h}$ after seeding and before irradiation treatment.

\section{Irradiation}

Using the Linac Siemens Oncor Expression (Healthcare Sector Siemens AG, Erlangen, Germany), the cells were irradiated $48 \mathrm{~h}$ after seeding at a dose rate of $3.75 \mathrm{~Gy} / \mathrm{min}$. The irradiation doses used were $0.5 \mathrm{~Gy}, 2 \mathrm{~Gy}, 4 \mathrm{~Gy}$, and $6 \mathrm{~Gy}$. Sham irradiated samples were used as negative control.

\section{Growth curves}

$1 \times 10^{4}$ cells were seeded as triplicates in multi-well plates for each SVA value. After $24 \mathrm{~h}$, SVA was added in different concentrations. By using $0.25 \%$ trypsin/EDTA solution (Biochrom $\mathrm{GmbH}$ ), the cell number of three untreated wells 
was determined at the same time point. Up to six days after the SVA application, the cell number for each SVA value and control was detected.

\section{Measurement of cytotoxicity}

Two days before IR treatment, the MCF10A $\left(2 \times 10^{3}\right)$ and MCF-7 $\left(7.5 \times 10^{3}\right)$ cells of both cell lines were seeded in multi-well plates as triplicates for each dose value. Subsequently, SVA was added $24 \mathrm{~h}$ later. Using the Pierce LDH Cytotoxicity Assay Kit (Thermo Fisher Scientific, Darmstadt, Germany), the cytotoxicity was detected for each value. The LDH Cytotoxicity Assay Kit was performed in keeping with the manufacturer's instructions. Based on the principle that the accessible enzyme lactate dehydrogenase can metabolize the tetrazolium salt into formazan only in dead cells, the metabolized formazan dye quantity is directly correlated with the number of dead cells. The measurement was performed with an ANTHOS zenyth 340r reader (Anthos Mikrosysteme GmbH, Krefeld, Germany).

\section{Immunostaining of DSBs via $\mathrm{pH} 2 \mathrm{AX}$ antibody}

Two days before IR treatment, $5 \times 10^{4}$ (MCF-7) or $2.5 \times 10^{4}$ (MCF10A) cells per well $\left(1.8 \mathrm{~cm}^{2}\right)$ were seeded as duplicates in chamber slides (LabTek ${ }^{\circledR}$, Nunc, Roskilde, Denmark). The addition of SVA was performed $24 \mathrm{~h}$ later. After fixation with $2 \%$ formaldehyde and permeabilization with $0.25 \%$ triton-X 100 (both Sigma Aldrich Chemie GmbH, Munich, Germany), the cells were consecutively incubated for $60 \mathrm{~min}$ with the anti- $\gamma \mathrm{H} 2 \mathrm{AX}$ antibody (1:500, clone JBW301, Merck Millipore) and Alexa Fluor 594 goat anti-mouse IgG1 (1:400, Molecular Probes ${ }^{\circledR} /$ Life Technologies, Darmstadt, Germany) for $30 \mathrm{~min}$. The slides were mounted with Vectashield ${ }^{\circledR}$ containing anti-4',6-diamidino-2-phenylindole (DAPI; Vector Laboratories, Inc., Burlingame, CA). The foci were visualized with an Eclipse TE300 inverted microscope (Nikon, Tokyo, Japan). At the magnification of 1000x, the foci of 50 cells per chamber were counted; two chambers per SVA concentration and irradiation dose were analysed.

\section{Colony-forming assay in 2D culture}

Two days before the IR treatment, $1 \times 10^{3}$ cells of MCF10A, MCF7 and MDA-MB-231 cell lines were seeded in $25 \mathrm{~cm}^{2}$ cell culture flasks as duplicates for each dose value. Subsequently, SVA was added after $24 \mathrm{~h}$. A medium exchange was performed two days (MCF10A) or five days (MCF-7, MDA-MB-231) after the IR treatment. Eight days (MCF10A), 10 days (MDA-MB-231) or 14 days (MCF-7) after the seeding, the colonies were fixed with $70 \%$ ethanol for $10 \mathrm{~min}$ and stained for 5-10 min with $1 \%$ crystal violet solution (Serva Electrophoresis $\mathrm{GmbH}$, Heidelberg, Germany). Colonies comprising 50 cells and more were counted. Afterwards, the survival fraction $(\mathrm{SF})$ was determined.

\section{Colony-forming assay in 3D culture}

For the colony-forming assay (CFA) performed in threedimensional (3D) cultures [25], the multi-well plates were pre-coated with agarose (Thermo Fisher Scientific GmbH, Dreieich, Germany) in a final concentration of $1 \%$. Afterwards, the $1 \times 10^{3}$ cells, embedded in growth factorreduced Matrigel ${ }^{\mathrm{TM}}$ (Corning Incorporated, NY, USA) with a final protein concentration of $0.5 \mathrm{mg} / \mathrm{ml}$, were plated on the agarose layer $48 \mathrm{~h}$ before irradiation. Analogous to the CFA in 2D, SVA was added $24 \mathrm{~h}$ before the IR treatment. CFA in 3D were cultured under standard conditions. A medium exchange was performed once a week. For SF determination, the unfixed and unstained colonies were counted after 14 days.

\section{Cell cycle analysis}

Cells were seeded in an appropriate density followed by medium exchange with serum free medium $24 \mathrm{~h}$ after cell seeding to induce synchronisation of cell cycle. Further $24 \mathrm{~h}$ later, SVA was added in different concentrations $(0.05 \mu \mathrm{M}$, $0.1 \mu \mathrm{M}, 0.5 \mu \mathrm{M}, 1 \mu \mathrm{M})$. The irradiation with single-doses of 2 Gy or 0 Gy (control) for each experimental approach was performed $24 \mathrm{~h}$ after SVA addition and carried out at least in three independent experiments. $24 \mathrm{~h}$ or $72 \mathrm{~h}$ after irradiation cells were fixed and permeabilized $10 \mathrm{~min}$ in ethanol $(70 \%(\mathrm{v} /$ v), $\left.-20{ }^{\circ} \mathrm{C}\right)$, and stained with propidium iodide $(75 \mu \mathrm{M})$. Samples were measured on flow cytometer Cytomics FC 500 (Beckman Coulter, Krefeld, Germany). Analysis was performed using Multicycle for Windows, version 3.0 (Phoenix Flow Systems, San Diego, USA).

\section{Measurement of marker survivin, CTGF and ERK1}

To determine the release of survivin, human connective tissue growth factor (CTGF) and extracellular signal-regulated kinase 1 (ERK1) enzyme-linked immunosorbent assays (ELISA) were used. $1 \times 10^{4} \mathrm{MCF} 10 \mathrm{~A}$ or $1 \times 10^{4} \mathrm{MCF}-7$ cells were seeded into each well of a 12-well plate. $1 \mu \mathrm{M}$ of SVA was added $24 \mathrm{~h}$ later. At the end point of $48 \mathrm{~h}$ after irradiation, culture medium samples were collected, centrifuged, shockfrozen by means of nitrogen and stored at $-80{ }^{\circ} \mathrm{C}$ until assayed. Simultaneously, the cells were detached by $0.05 \%$ trypsin/EDTA solution and centrifuged at $250 \mathrm{x}$ g. Cell pellets were washed twice with PBS and lysed at $1 \times 10^{7}$ cells $/ \mathrm{ml}$ Lysis Buffer (R \& D Systems, USA) on ice. The concentration of survivin and CTGF in the cell culture supernatant was assayed using the Human Survivin Quantikine ELISA Kit and the Human/CCN2 DuoSet ELISA (R \& D Systems). The content of ERK1 in cell lysates was determined using 
the Human Total ERK1 DuoSet IC ELISA (R\&D Systems). Optical densities were read using Anthos Zenyth 340 Plate Reader. The respective standard curves and protein concentrations were calculated via "Four Parameter Logistic Curve" online data analysis tool, MyAssays Ltd., 24 th. November 2012, http://www.myassays.com/four-parameter-logisticcurve.assay.

\section{Statistical analysis}

Data of at least three independent experiments is represented in all figures as mean values \pm standard deviation (SD) or standard error of mean (SEM). A value of $p<0.05$ was considered to indicate a statistically significant difference. For comparing the sphere numbers, the statistical significance to the unirradiated control of each dimension (2D and 3D) was calculated via the one-sample t-test and a value of $p<0.02$ indicated a statistically significant difference.

\section{Results}

\section{Investigation of cell growth and potential cytotoxicity after SVA treatment}

Only compounds are defined as radiosensitizer in a narrower sense, which increase the effect of radiotherapy but do not have a cytotoxic effect even in the administered concentration [26]. Therefore the first step was to find a concentration of SVA that is non-toxic to both cell lines and that could then be used for all further experiments. The MCF10A and MCF-7 cells were treated with different concentrations of SVA and cell growth was analysed (Fig. 1). In both cell lines, the cell number was affected with increasing SVA concentrations in a dose-dependent manner. The MCF10A normal cells were more sensitive than the MCF-7 tumour cells. The MCF10A cells treated with $3 \mu \mathrm{M}$ showed a stagnation of the cell number during the experiment, which was significant from Day 3, whereas the MCF-7 cells treated with the same SVA concentration showed only slightly lower cell amounts compared to the untreated control cells. Additionally, the cytotoxicity of these different doses of SVA was determined by using the LDH assay. All the tested SVA concentrations showed no cytotoxicity on both cell lines (Supplement 1). As described above, a SVA concentration was needed which would not affect the MCF10A and MCF-7 cells on its own. By using cytotoxic analysis and growth curves, SVA concentrations up to $1 \mu \mathrm{M}$ were identified for further analyses.

\section{Repair capacity and residual $\mathrm{\gamma H} 2 \mathrm{AX}$ foci induction}

The detection of $\gamma \mathrm{H} 2 \mathrm{AX}$ foci was performed to determine the number of DNA double-strand breaks for investigating the
DNA repair capacity after treatment with SVA and irradiation. The $\gamma \mathrm{H} 2 \mathrm{AX}$ foci were analysed at an early time point, $30 \mathrm{~min}$ after the IR treatment and after a repair time of $24 \mathrm{~h}$ (Fig. 2).

Overall, it could be observed that the number of $\gamma \mathrm{H} 2 \mathrm{AX}$ foci was clearly higher in the MCF-7 cells than MCF10A. As expected, an irradiation of 2 Gy increased the number of $\gamma \mathrm{H} 2 \mathrm{AX}$ foci in both cell lines $30 \mathrm{~min}$ after the IR treatment. The influence of SVA within this time point was mostly not significant. Only a treatment with $0.5 \mu \mathrm{M}$ on the MCF-7 cells showed significant changes. It also indicates that in comparison with control without the drug with increasing concentrations of SVA, the number of $\gamma \mathrm{H} 2 \mathrm{AX}$ foci decreased for MCF10A. But this effect was reversed for MCF-7, while the number of $\gamma \mathrm{H} 2 \mathrm{AX}$ foci increased with increasing SVA concentrations compared to control.

Also, $24 \mathrm{~h}$ after the irradiation, a different pattern of the $\gamma \mathrm{H} 2 \mathrm{AX}$ foci number within the two cell lines was observed. In the MCF10A cells, increasing SVA concentrations caused a continuous elevation in the mean number of DSBs for the irradiated cells, which was significant for $0.1 \mu \mathrm{M}$ and $1 \mu \mathrm{M}$ of SVA. Without irradiation, the number of $\gamma \mathrm{H} 2 \mathrm{AX}$ foci was not affected in the MCF10A cells. In the MCF-7 cells, a concentration of $1 \mu \mathrm{M}$ of SVA showed an increase of DSBs - this was significant when the cells were additionally irradiated; lower doses of SVA caused no increase in the number of $\gamma \mathrm{H} 2 \mathrm{AX}$ foci. Interestingly, the unirradiated MCF-7 cells seemed sensitive for SVA; $0.1 \mu \mathrm{M}$ and $0.5 \mu \mathrm{M}$ elicited a decrease in the number of $\gamma \mathrm{H} 2 \mathrm{AX}$ foci, whereas $1 \mu \mathrm{M}$ of SVA slightly increased the amount of $\gamma \mathrm{H} 2 \mathrm{AX}$ foci.

\section{Clonogenic survival of cells cultivated in 2D and 3D}

Using the clonogenic survival assay, long-term effects after the SVA treatment and radiation were investigated. In general, without irradiation, the number of colonies from the MCF 10A cells decreased with increasing SVA concentrations compared to untreated control (Fig. 3). In 2D, significant changes were detected at $1 \mu \mathrm{M}$ SVA and higher concentrations. In contrast, in 3D, the colony formation of the MCF 10A cells was already affected in lower concentrations $(0.1 \mu \mathrm{M}$ up to $3 \mu \mathrm{M})$. For the MCF-7 cells, a significant influence of SVA on the number of colonies was not observable.

After the irradiation treatment for all concentrations of SVA and the control ( $0 \mu \mathrm{M} \mathrm{SVA})$, a dose-dependent decrease in the survival fraction (SF) could be observed (Fig. 4). However, for the MCF-7 cells, this effect was different between the cells cultivated in 2D and 3D. The MCF-7 cells were more radiosensitive when cultured in $2 \mathrm{D}$ with a survival fraction at $6 \mathrm{~Gy}$ (SF6) of $1.8(0 \mu \mathrm{M} \mathrm{SVA})$ and only $0.1(1 \mu \mathrm{M}$ SVA; Fig. $4 \mathrm{~b}$ (I)). On the other hand, in the 3D cell culture, the SF6 of MCF-7 cells decreased to $6.4(0 \mu \mathrm{M} \mathrm{SVA})$ and 8.0 ( $1 \mu$ M SVA; Fig. 4b (II)). Such a different effect of the SF after $2 \mathrm{D}$ and $3 \mathrm{D}$ cell cultivations was not observed in the 
Fig. 1 Growth curves of normal cells MCF10A (a) and tumour cells MCF-7 (b) under influence of simvastatin. Simvastatin (SVA) was added in different doses $24 \mathrm{~h}$ after seeding. Every day triplicates were scored for both cell lines. Data from three independent experiments are presented as mean values $\pm \mathrm{SD}$. Asterisks illustrate significances: $* * p<0.01, * * * p<0.001$
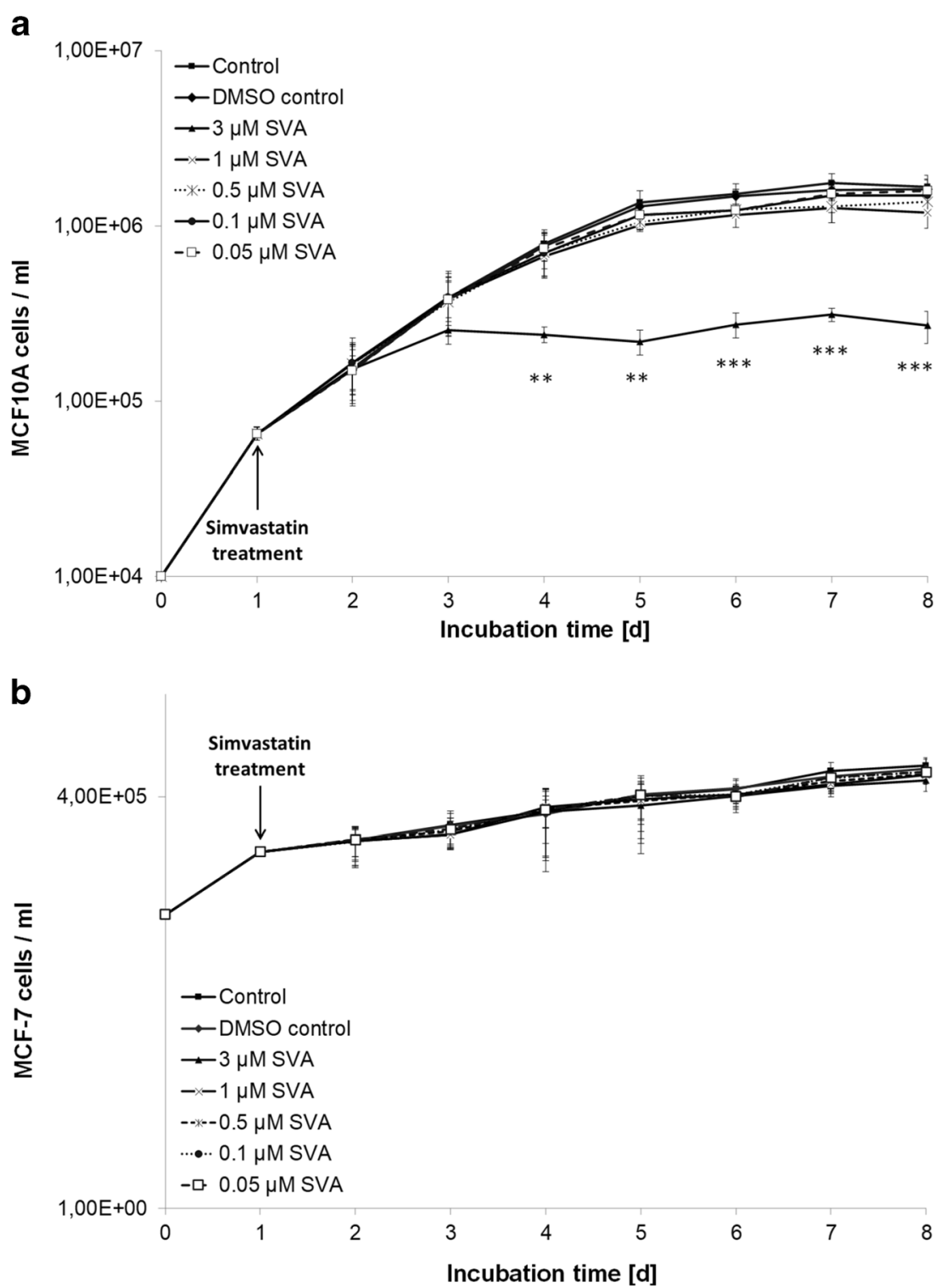

MCF10A cells. Cultivated in 2D, the SF6 of the MCF10A cells were $3.3(0 \mu \mathrm{M}$ SVA) and 1.5 (3 $\mu \mathrm{M}$ SVA), whereas in 3D the SF6 were 2.1 ( $0 \mu \mathrm{M} \mathrm{SVA})$ and 1.1 (3 $\mu \mathrm{M} \mathrm{SVA}$; Fig. $4 \mathrm{a}$ (I) and A (II)). Next to this, in both $2 \mathrm{D}$ and $3 \mathrm{D}$, no radioprotective effect of SVA could be observed on normal breast cells, namely MCF10A.

\section{Distribution of cell cycles}

To investigate the cell cycle distribution of A) MCF10A and B) MCF-7 cells, flow cytometry was used to determine the ratio of cell cycle phases (Fig. 5). Generally, treatment with SVA did not influence the distribution of cells in the cell cycle phases of both cell lines, regardless of whether cells were nonirradiated or irradiated. Only after a high SVA concentration $(1 \mu \mathrm{M}) 48 \mathrm{~h}$ after treatment with the drug an increase of MCF10A cells in G0G1 phase and a significant decrease of cells in S phase could be observed. Additional irradiation had an clear effect on cell cycle distribution only in normal cells, resulting in an accumulation of cells being in G0/G1 phase. However, this effect was independently of SVA treatment.

Additionally, after treatment with SVA ( \pm irradiation) in both cell lines no sub-G1 fraction as an indication of an apoptosis could be detected. The extension of incubation time to $72 \mathrm{~h}$ after irradiation showed similar effects on cell cycle distribution for cells.

\section{Expression of marker survivin, CTGF and ERK1}

Since it is known that SVA treatment in combination with ionizing radiation influences the expression of survivin and connective tissue growth factor (CTGF) as well as extracellular-signal regulated kinase 1 (ERK1), all three markers in the breast cells were examined in more detail after 
MCF10A

\section{a(I) $30 \mathrm{~min}$}

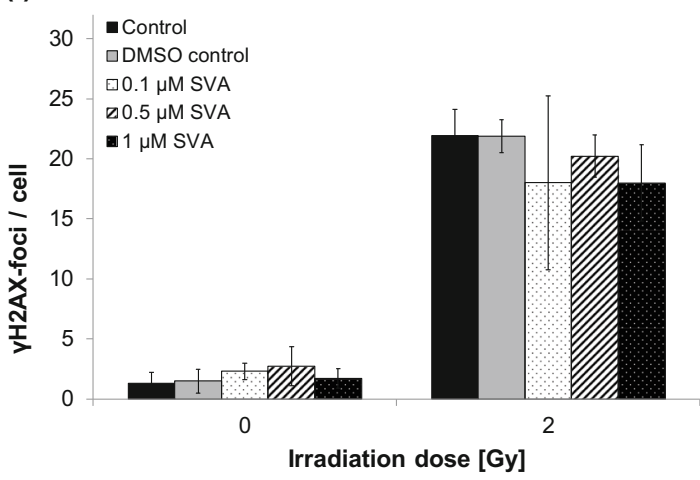

a(II) 24 hours

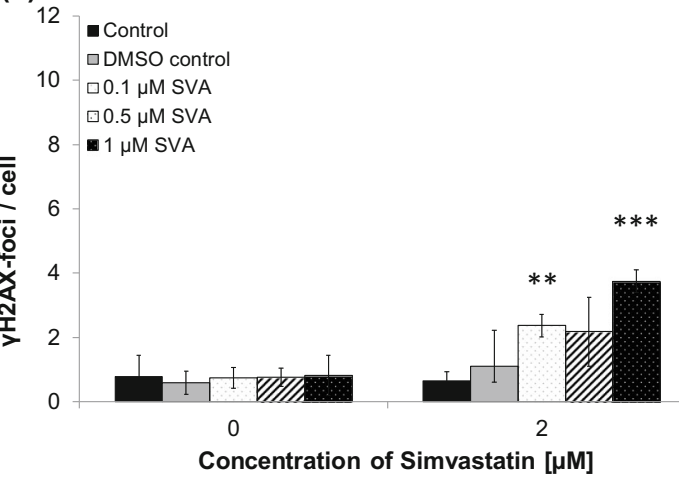

Fig. 2 DNA double-strand breaks under different simvastatin concentration after irradiation. $\gamma \mathrm{H} 2 \mathrm{AX}$ foci were scored in MCF10A (a) and MCF-7 (b) cells $30 \mathrm{~min}$ (I) and $24 \mathrm{~h}$ (II) after radiation with $2 \mathrm{~Gy}$ and treatment with different doses of simvastatin $(0.1 \mu \mathrm{M}, 0.5 \mu \mathrm{M}$ and $1 \mu \mathrm{M}$

treatment (Fig. 6). Except for ERK1 there was a clear difference in content between the normal MCF10A cells and the MCF-7 tumour cells for the markers. As was to be expected, the survivin level in the tumour cells was higher than in the normal cells; it was the other way round for CTGF levels. However, neither after treatment with SVA or radiation alone nor in a combination of both applications a change in the marker level of survivin and CTGF was detectable. For ERK1, the expression was approximately at the same level in both cell lines. Individual treatment with the drug did not show any change in the ERK1 level. However, the combination of both therapies led to an significant increase in the marker content, but only in the MCF-7 tumour cells.

\section{Discussion}

To investigate the influence of SVA on the radiation response of cancer cells and normal tissue cells of the human breast, the present study examined different radiobiological effects following the SVA treatment in combination with IR. Currently, there are limited experimental studies which examine the effect of SVA on normal and cancer cells of the human breast at the same time.

MCF-7

\section{b(I) $30 \mathrm{~min}$}

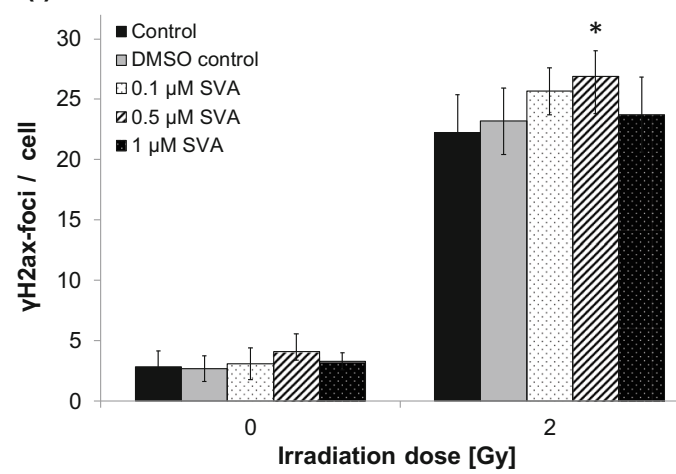

b(II) 24 hours

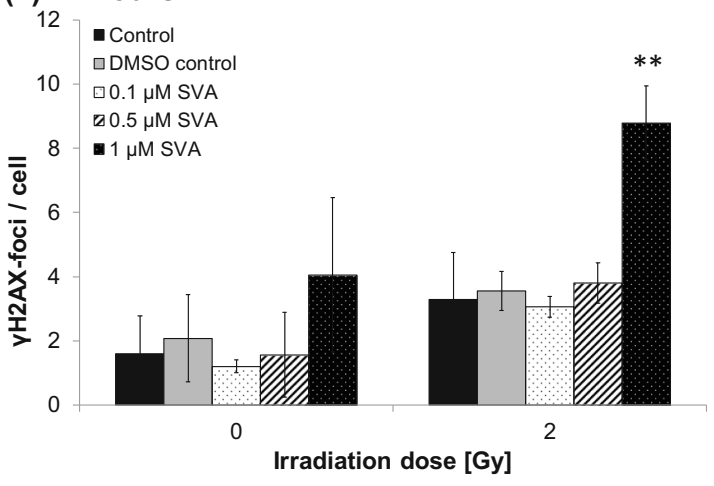

SVA). Data from three (MCF10A) and four (MCF-7) independent experiments are presented as mean values $\pm \mathrm{SD}$. Asterisks illustrate significances: $* p<0.05, * * \mathrm{p}<0.01, * * * \mathrm{p}<0.001$

To examine any potential radiosensitizing or radioprotecting effect, an SVA concentration was needed which would not affect the MCF10A and MCF-7 cells on its own. By using cytotoxic analysis and growth curves, SVA concentrations up to $1 \mu \mathrm{M}$ were identified for further studies. An SVA concentration of $3 \mu \mathrm{M}$ did not affect the MCF-7 cells but caused a stagnation of MCF10A cell growth. Higher SVA concentrations, such as a concentration of $12.5 \mu \mathrm{M}$, caused an inhibition of cell growth in both cell lines (Supplement 2).

It could be assumed that the cytotoxic level of SVA differs between various cell types. For natural killer cells, an inhibition of the proliferation after $50 \mu \mathrm{M}$ SVA could be observed [27]. Next to this, Crescencio et al. (2009) have analysed three cervical cancer cell lines and described strongly differed responses to SVA $(10 \mu \mathrm{M}$ up to $160 \mu \mathrm{M})$. The proliferation of CaSki- and ViBo cells was dose-dependently decreased, whereas HeLa cells showed an increase in the proliferation after $10 \mu \mathrm{M}$ SVA, and afterwards, a dose-dependent decrease [28].

In further experiments, we investigated the effect of SVA on the radiation response of the two cell types. Except of the investigation of the clonogenic survival, an irradiation dose of 2 Gy as clinical relevant dose $[29,30]$ was used.

Early and residual $\gamma \mathrm{H} 2 \mathrm{AX}$ foci were measured to investigate the influence of SVA on the DNA repair capacity after 
IR. At an early time-point after IR, it indicates that with increasing concentration of SVA, the number of $\gamma \mathrm{H} 2 \mathrm{AX}$ foci decreased for MCF10A. But this effect was reversed for $\mathrm{MCF}-7$ - the number of $\gamma \mathrm{H} 2 \mathrm{AX}$ foci increased with increasing SVA concentrations. Determining the residual foci, a different pattern of the $\gamma \mathrm{H} 2 \mathrm{AX}$ foci number within the two cell lines was observed. In the MCF10A cells, increasing SVA concentrations caused a continuous increase in the mean number of DSBs for the irradiated cells. Without irradiation, the number of $\gamma \mathrm{H} 2 \mathrm{AX}$ foci was not affected in the MCF10A cells. In the MCF-7 cells, a concentration of $1 \mu \mathrm{M}$ of SVA showed a significant increase in DSBs after the IR treatment. Lower doses of SVA caused no increase in the number of $\gamma \mathrm{H} 2 \mathrm{AX}$ foci. Interestingly, the unirradiated MCF-7 cells seemed sensitive for SVA- $0.1 \mu \mathrm{M}$ and $0.5 \mu \mathrm{M}$ elicited a decrease in the number of $\gamma \mathrm{H} 2 \mathrm{AX}$ foci-whereas $1 \mu \mathrm{M}$ of SVA slightly increased the number of $\gamma \mathrm{H} 2 \mathrm{AX}$ foci. So, SVA
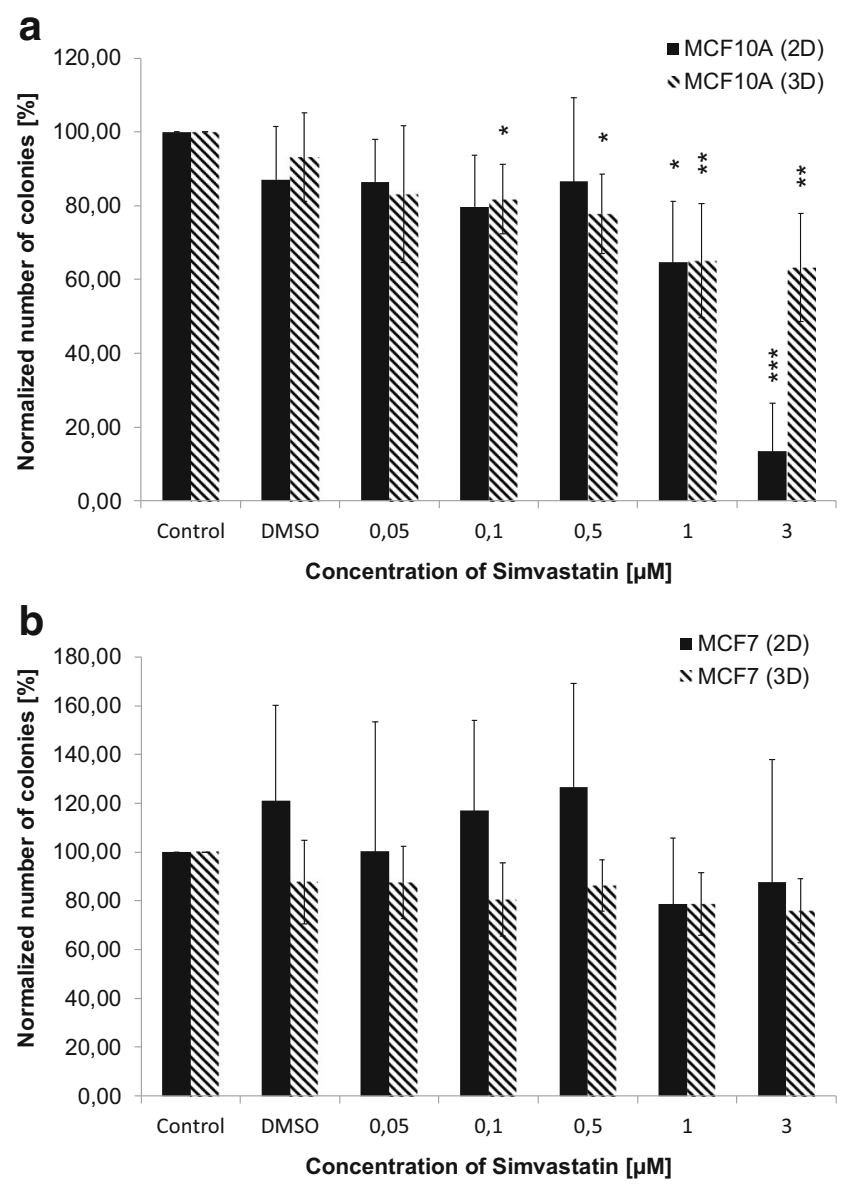

Fig. 3 Comparison of the effects of simvastatin (SVA) on colony formation in 2D and 3D without radiation. SVA treatment was performed $24 \mathrm{~h}$ after seeding of MCF10A (a) and MCF-7 (b). The amount of colonies was determined two weeks after seeding. Data from at least three independent experiments are presented as normalized mean values of numbers of colonies $\pm \mathrm{SD}$. Statistical analysis was performed by using one-sided t-test. Asterisks illustrate significances: $* p<0.02$, $* * \mathrm{p}$ $<0.01, * * * p<0.002$ has an influence on the repair capacity of the cells, but this is not very clear: it is seen that $30 \mathrm{~min}$ after IR this effect is rather protective for MCF10A, whereas $24 \mathrm{~h}$ after irradiation it is rather sensitizing for MCF10A and MCF-7. Chen et al. (2018) have also observed an increase in the number of foci after a combination of SVA and radiotherapy $(100 \mu \mathrm{M}$ of SVA, 2 Gy) on prostate epithelial cells [31]. Interestingly, the number of foci was clearly affected in MCF-7 only by SVA at $24 \mathrm{~h}$; the number increased for $1 \mu \mathrm{M}$ and decreased for $0.1 \mu \mathrm{M}$ and $0.5 \mu \mathrm{M}$.

This fact could be explained by the interaction between SVA and the key player in epigenetic regulation, as well as by further epigenetic changes like the downregulation of histone deacetylases - this effect of the SVA treatment was detected by Karlic et al. (2015) on different tumour cells [22]. Owing to this, it is possible that SVA could affect the number of $\gamma \mathrm{H} 2 \mathrm{AX}$ foci only by its epigenetic change capabilities.

After determining the influence of SVA on DNA repair capacity, the clonogenic survival was examined for further investigation concerning the long-term effects of a potential radiosensitization or radioprotecting effect of SVA. During the $2 \mathrm{D}$ cultivation, a radiosensitizing effect on MCF-7 and MCF10A was observable, especially at 6 Gy. For other cell types, such as gastric cancer, a synergistic effect of radiation and SVA $(0.2 \mu \mathrm{M})$ was also observed [16]. In another study, four colorectal cancer cell lines also confirmed the radiosensitizing effect of SVA, a decreased number of colonies after the SVA treatment ( $1 \mu \mathrm{M}$ and $2 \mu \mathrm{M})$, and a decreasing viability after a combined treatment with SVA and IR has been shown. [15]. Considering MCF10A as a representative of normal breast epithelial cells, it could be assumed that SVA had a small protective function. This could be attributed to the fact that at a concentration of $2.5 \mu \mathrm{M}$ SVA, MCF10A cannot undergo a FGF2-driven malignant transformation in $3 \mathrm{D}$ cell cultures (led by using ultra-low attachment plates) [32].

It could be shown that the SVA-dependent radiation response varies within different breast cancer subtypes. MCF7 cells are estrogen receptor $(\mathrm{ER})^{+}$; progesterone receptor $(\mathrm{PR})^{+}$, and Her2neu ${ }^{-}$[33]. Epidemiological studies show that the receptor status of patients play an important role for the effectiveness of SVA. Because statin use is not associated with an improved overall survival of triple negative breast cancer patients [12], but a small subset of patients with $\mathrm{ER}^{+}$ tumours benefit from the use of statins [7]. It was also detected that MCF-7 cells, which are ER ${ }^{+}$, were not so strongly affected, like MDA-MB231 cells, as the representative for triple negative breast cancer [34]. But their experimental data is contrary to the epidemiological data from Shaitelman et al. (2017) [12] which showed no effect of statins in the cohort of triple negative breast cancer patients. So, it is conceivable that other breast cancer cell lines may respond differently to 
the SVA treatment depending on the severity of hormone receptors. But even the analysis of the combined effect of SVA and irradiation using a cell line with a different hormone receptor status, such as the triple negative breast cancer cell line MDA-MB231, showed no different results of clonogenic survival in comparison with the MCF-7 cells $\left(\mathrm{ER}^{+}, \mathrm{PR}^{+}\right.$, Her2neu ; Supplement 3). Next to the hormonal status, the influence of inflammatory status of the breast cancer type could be important. If the effect on a particular cell type, such as mammosphere-initiating cells, within different types of breast cancer was investigated, a radioprotective effect of SVA on MCF-7, as a representative of non-inflammatory breast cancer, was shown in 2D and $3 \mathrm{D}$ cell cultures. Moreover, different cell lines of inflammatory breast cancer were radiosensitized by using SVA [35]. In contrast, the 3D culture was performed by using ultra-low attachment plates and not by a cell culture matrix like Matrigel ${ }^{\mathrm{TM}}$. Furthermore, the colony formation assays were only incubated for seven days, whereas 14 days of incubation were used in the present study. The different results of the present study and Lacerda et al. (2014) could possibly justified by focusing on different

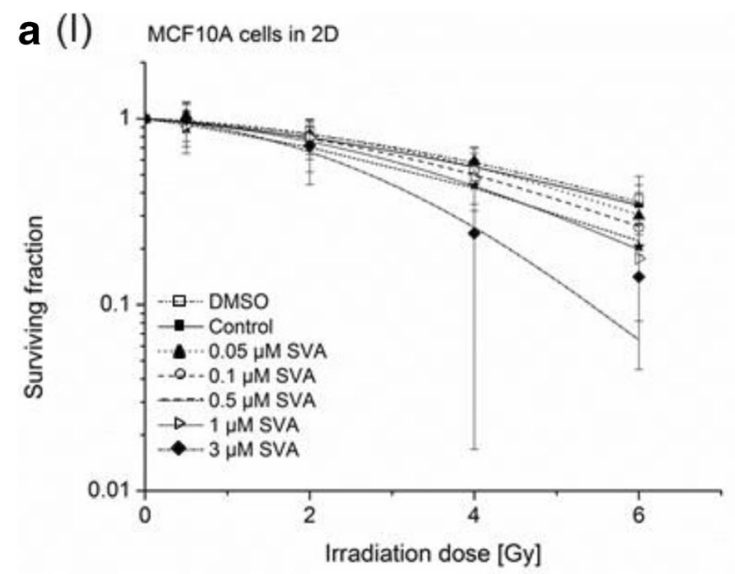

a (II) MCF10A cells in 3D

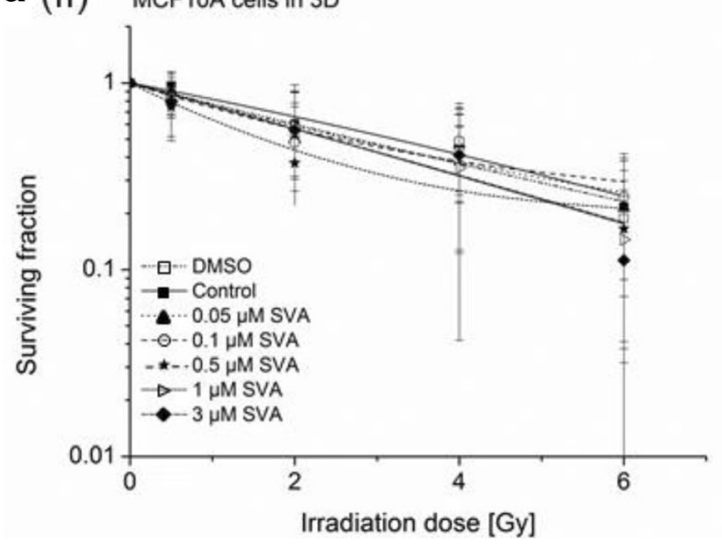

Fig. 4 Clonogenic survival after simvastatin (SVA) treatment of normal cells MCF10A (a) and tumour cells MCF-7 (b) in 2D (I) and 3D (II). SVA treatment was performed $24 \mathrm{~h}$ after seeding and $24 \mathrm{~h}$ cell populations. As Lacerda et al. (2014) caused an enrichment of the cancer stem/progenitor cell population by using ultra-low attachment plates, basic fibroblast growth factor, epidermal growth factor, and B27 supplement. But no enrichment or selection of MCF10A cells was performed in the present study.

Moreover, it was interesting that the type of cultivation in 2D and 3D clearly affected the radiation response of MCF-7 at all doses after the SVA treatment. MCF-7 cells were much more radioresistant in $3 \mathrm{D}$, while MCF10A cells were not affected as much. The radiation sensitivity of MCF10A in 2D and 3D did only differ at high irradiation doses. Several studies on mammary gland models have shown that the responses between 2D and 3D systems to irradiation can vary [36, 37]. Many differences could be found in breast cells when they are cultivated in 3D instead of 2D [38]. If mammary cells are cultivated in 2D, then crucial signals for metabolism, cell proliferation, differentiation, and cell death responsible for the formation of correct tissue-specific architecture and functions are lost $[39,40]$. In addition to differences in the morphology and functional parameter of mammary cells, it has also been
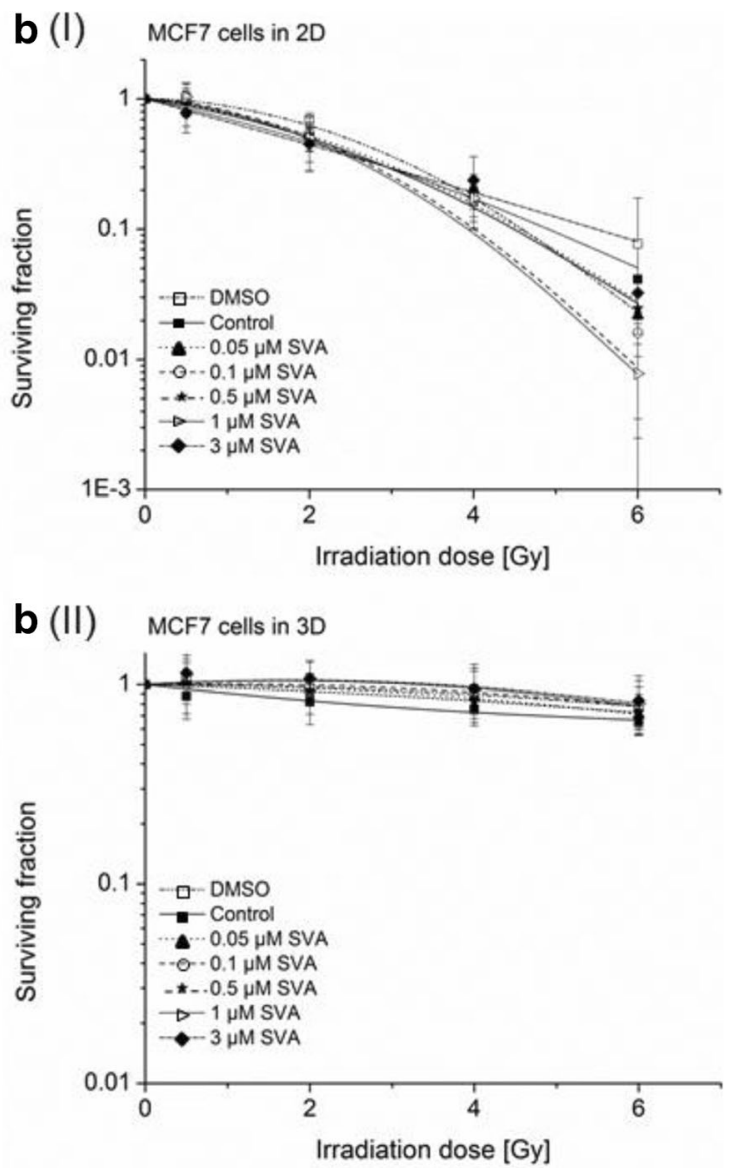

before irradiation treatment of cells. Data from at least three independent experiments are presented as normalized mean values of numbers of colonies \pm SD. Statistical analysis was performed by Students t-test 
shown that, the tissue-specific gene expression and signalling pathways in 3D cultures are differently regulated than in cells cultivated in 2D cultures $[39,41]$. In our study, the breast cancer cells were much more radioresistant in $3 \mathrm{D}$ - this has already been confirmed by Hehlgans et al. (2008) and substantiated with altered protein expressions and morphology [25]. The altered morphology and cellular association within the 3D culture may possibly influence the efficacy of SVA. For pancreatic carcinoma cells, it was already shown that the effectiveness of some drugs, such as gemcitabine and microtubule-inhibitors, decreased in 3D cultures compared to the $2 \mathrm{D}$ cultures [42]. Recently it was also shown that in pancreatic carcinoma the effect of statins were reduced in 3D compared to $2 \mathrm{D}$ cultures [43].

The influence of SVA on the cell cycle has been shown many times in the literature. After treatment with the drug, cell cycle arrests have been described which, depending on the cell type, occurred in the G0/G1 phase or the G2/M phase [44-46]. For example, a significant change in the cell cycle was found in MCF-7 cells due to a standstill in the G1 phase after SVA treatment [47]. The SVA concentrations used, at $2.5 \mu \mathrm{M}$ and $40 \mu \mathrm{M}$, were significantly higher than in our studies. We observed that treatment with SVA at the nontoxic concentrations used generally did not affect the distribution of cells in the cell cycle phases of both cell lines, regardless of whether the cells were irradiated or not. Only after the higher concentration of $1 \mu \mathrm{M}$ SVA an increase of MCF10A cells in G0G1 phase accompanied by a decrease of $\mathrm{S}$ phase cells could be detected. As already observed in the growth curves, the normal MCF10A cells were more sensitive than the MCF-7 tumour cells. During analyses of cell cycle distribution no SubG1 cells, an indication for apoptosis, could be observed. Cell death via apoptosis is characterized by DNA fragmentation. On the basis of their reduced DNA content, including nuclear condensation, which can be detected by flow cytometry as sub-G1 peak, apoptotic cells can be identified and quantified [48]. The results in our study revealed that as expected SVA treatment in the used concentrations may not induce apoptosis.

In recent studies it was shown, that SVA suppresses gene expression of survivin and the connective tissue growth factor (CTGF) in gastric and colorectal cancer cells [16]. These observations led those authors suppose that both, as radiationsensitive genes known factors, may play an important role in SVA mediated enhancement of radiation sensitivity [16]. Based on the results of our study with breast cells we cannot confirm this conclusion. Although we observed a radiationsensitizing effect in 2D in the colony formation assay, we a(l)

\section{4 hours after IR} $120 \%$

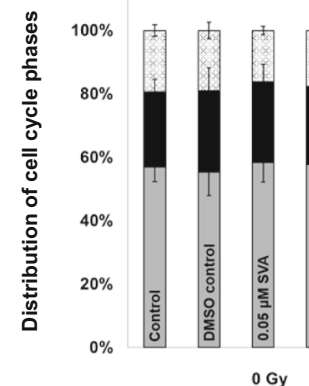

a(II)

72 hours after IR $120 \%$

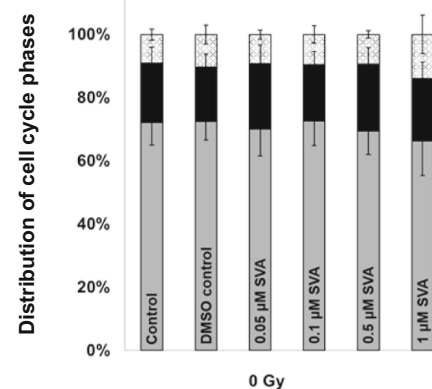

MCF10A

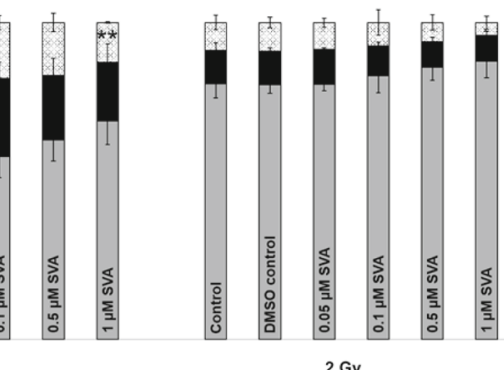

Gy

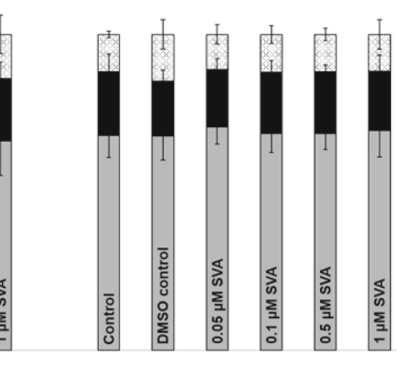

2 Gy
b(I)

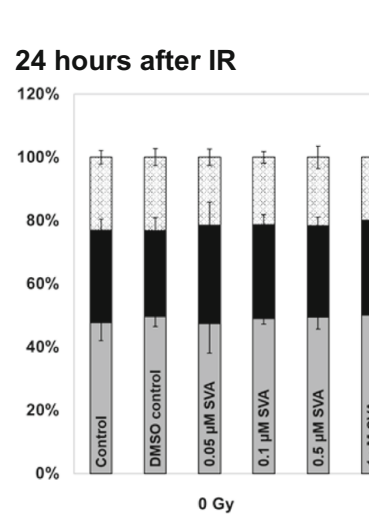

b(II)
MCF-7

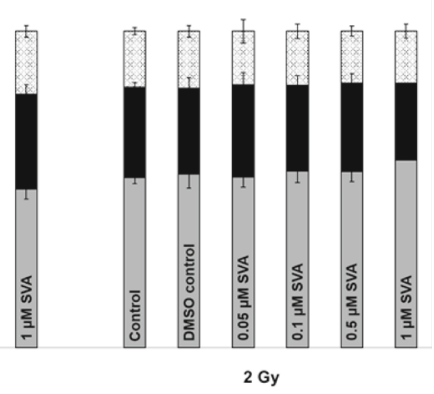

$120 \%$

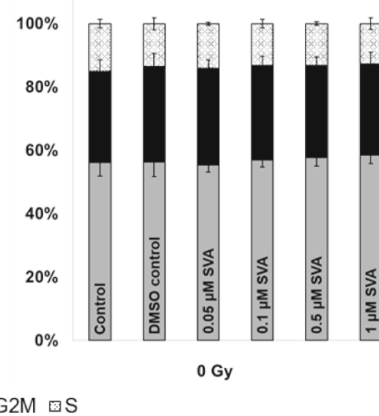

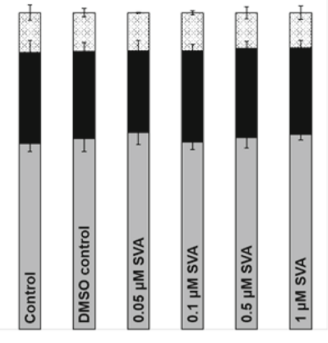

2 Gy

$\square \mathrm{G} 0 \mathrm{G} 1-\mathrm{G} 2 \mathrm{M} \mathrm{g}$

the three independent experiments significances were calculated in relation to non-irradiated controls without SVA treatment and illustrated by asterisks $* * p \leq 0.005$ 
Fig. 6 Level of Survivin (I), Connective Tissue Growth

Factor (CTGF, II) in

supernatant and human extracellular signal-regulated kinase 1 (ERK1, III) in cell lysate of MCF10A (a) and MCF-7 (b) cells after therapy with simvastin (SVA) or/and irradiation. The protein concentrations of these marker were determined by ELISA, $48 \mathrm{~h}$ after irradiation with $2 \mathrm{~Gy}$. Results are illustrated as mean values $\pm \mathrm{SD}$ of three independent experiments. Asterisks illustrate significant differences: $* \mathrm{p}<0.05$, $* * p<0.005$. Statistical analyses were performed by two-tailed t-test
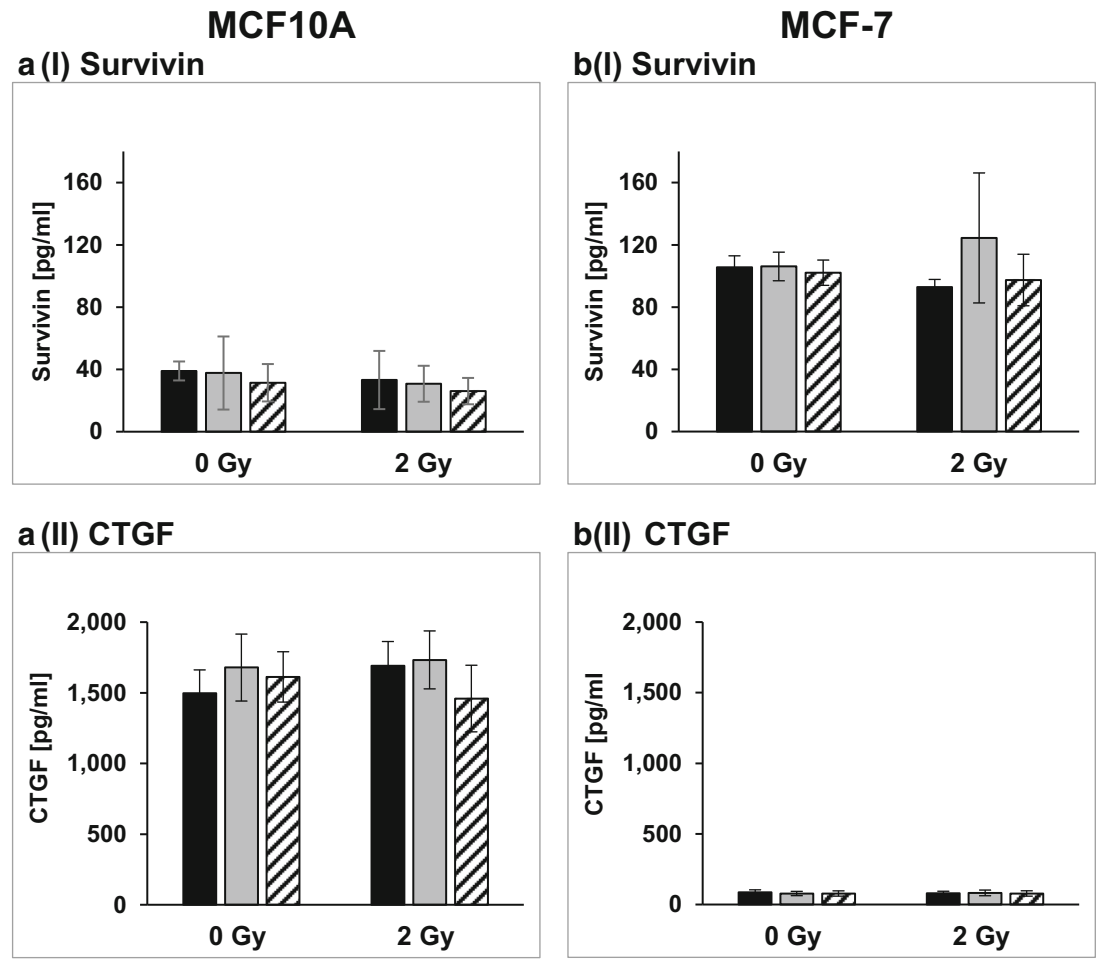

\section{a(III) ERK1}

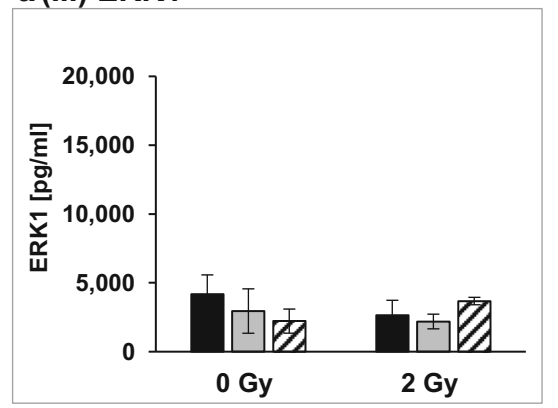

\section{b(III) ERK1}

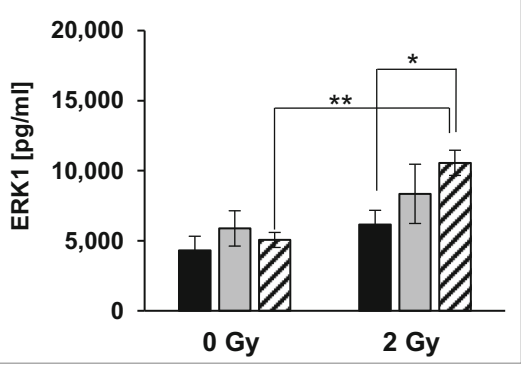

- Control aDMSO control $\nabla 1 \mu \mathrm{M}$ SVA

could not determine any effect on the expression of survivin or CTGF when using the same SVA concentration of $1 \mu \mathrm{M}$. Other authors, however, reported an increase of SVA levels in tumour cells after irradiation with doses from 1 Gy to 8 Gy [49]. As already described, we did not see this effect in the used breast cell lines either.

As for the marker ERK1, its expression in the MCF-7 tumour cells was slightly increased by the radiation alone, but increased significantly after a combined treatment with SVA and radiation. It has been described in the literature that even low radiation doses of $0.05 \mathrm{~Gy}$ can induce activation of the ERK in MCF-7 cells [50]. We could also observe this effect for higher radiation doses (2 Gy). Although ERK1/2 has also been reported for MCF10A cells as a sensitive marker for the stress reaction after ionizing radiation [51], we could not observe an significant effect on the normal cells in our investigations.

\section{Conclusion}

In our study, it has been proven that tumorigenic and nontumorigenic human breast cells are affected by SVA alone or in combination with IR in terms of cell growth, clonogenic survival, and their DNA repair capacity. The results suggest that SVA may have, depending on cultivation conditions, a potential for radiosensitization. It is, therefore, important to further investigate the role of SVA in relation to the extent of radiosensitization and how it could be used to positively influence the therapy of breast cancer or other tumour entities. Future research should clarify the molecular mechanisms of how SVA affects the cellular survival.

Electronic supplementary material The online version of this article (https://doi.org/10.1007/s10637-020-01046-6 ) contains supplementary material, which is available to authorized users. 
Authors' contributions DJ, PF, AS and AK performed experiments, acquired and analysed the data. DJ designed the study, KM and DJ wrote the manuscript. KM revised the manuscript. GH and KM contributed to materials and tools. All authors read and approved the final manuscript.

Funding Open Access funding enabled and organized by Projekt DEAL. The research was performed as part of the employment of the authors by University Medical Center Rostock, Germany. Additionally, it was partially funded by the University of Rostock (in line with the Women Professors Programme II of the federal government and the state governments) of Germany.

Data availability The data supporting this study are provided in the results section of this paper. Further datasets used and/or analyzed during the current study are available are stored by the authors at the University Medical Center Rostock.

\section{Compliance with ethical standards}

Conflicts of interests The authors declare that there are no competing interests.

Ethics approval This article does not contain any studies with human participants or animals performed by any of the authors.

Consent to participate Not applicable.

Consent for publication Not applicable.

Code availability Not applicable

Abbreviations 2D, Two-dimensional; 3D, Three-dimensional; CFA, Colony forming assay; CTGF, Connective tissue growth factor; DSB, Double strand break; ER, Estrogen receptor; ERK1, Extracellular-signal regulated kinase 1; HMG-CoA, 3-hydroxy-3-methylglutaryl coenzyme A; IR, Ionizing radiation; PR, Progesterone receptor; SF, Survival fraction; SF6, Survival fraction at 6 Gy; SVA, Simvastatin

Open Access This article is licensed under a Creative Commons Attribution 4.0 International License, which permits use, sharing, adaptation, distribution and reproduction in any medium or format, as long as you give appropriate credit to the original author(s) and the source, provide a link to the Creative Commons licence, and indicate if changes were made. The images or other third party material in this article are included in the article's Creative Commons licence, unless indicated otherwise in a credit line to the material. If material is not included in the article's Creative Commons licence and your intended use is not permitted by statutory regulation or exceeds the permitted use, you will need to obtain permission directly from the copyright holder. To view a copy of this licence, visit http://creativecommons.org/licenses/by/4.0/.

\section{References}

1. Goldstein JL, Brown MS (1990) Regulation of the mevalonate pathway. Nature. 343:425-430

2. Van Wyhe RD, Rahal OM, Woodward WA (2017) Effect of statins on breast cancer recurrence and mortality: a review. Breast Cancer (Dove Med Press) 9:559-565
3. Borgquist S, Bjarnadottir O, Kimbung S, Ahern TP (2018) Statins: a role in breast cancer therapy? J Intern Med 1-12

4. Murai T (2015) Cholesterol lowering: role in cancer prevention and treatment. Biol Chem 396:1-11

5. Strasser-Weippl K, Goss PE (2013) Suitable trial designs and cohorts for preventive breast cancer agents. Nat Rev Clin Oncol. Nature Publishing Group 10:677-687

6. Kwan ML, Habel LA, Flick ED, Quesenberry CP, Caan B (2008) Post-diagnosis statin use and breast cancer recurrence in a prospective cohort study of early stage breast cancer survivors. Breast Cancer Res Treat 109:573-579

7. Ahern TP, Pedersen L, Tarp M, Cronin-Fenton DP, Garne JP, Silliman RA, Sorensen HT, Lash TL (2011) Statin prescriptions and breast cancer recurrence risk: a Danish nationwide prospective cohort study. J Natl Cancer Inst 103:1461-1468

8. Beckwitt CH, Brufsky A, Oltvai ZN, Wells A (2018) Statin drugs to reduce breast cancer recurrence and mortality. Breast Cancer Res 20:144

9. Bjarnadottir O, Romero Q, Bendahl P-O, Jirström K, Rydén L, Loman N, Uhlén M, Johannesson H, Rose C, Grabau D, Borgquist S (2013) Targeting HMG-CoA reductase with statins in a window-of-opportunity breast cancer trial. Breast Cancer Res Treat 138:499-508

10. Cronin-Fenton D, Lash TL, Ahern TP, Damkier P, Christiansen P, Ejlertsen B et al (2018) Concurrent new drug prescriptions and prognosis of early breast cancer: studies using the Danish Breast Cancer Group clinical database. Acta Oncol. Informa UK Limited, trading as Taylor \& Francis Group 57:120-128

11. Gray RT, Loughrey MB, Bankhead P, Cardwell CR, McQuaid S, O'Neill RF et al (2017) Statin use, candidate mevalonate pathway biomarkers, and colon cancer survival in a population-based cohort study. Br J Cancer 116:1652-1659

12. Shaitelman SF, Stauder MC, Allen P, Reddy S, Lakoski S, Atkinson B, Reddy J, Amaya D, Guerra W, Ueno N, Caudle A, Tereffe W, Woodward WA (2017) Impact of statin use on outcomes in triple negative breast Cancer. J Cancer 8:2026-2032

13. Cruz P, Reyes F, Torres CG (2018) Simvastatin modulates $\beta$-catenin/MDR1 expression on spheres derived from CF41.Mg canine mammary carcinoma cells. Pol J Vet Sci 21:95-99

14. Sieczkowski E, Lehner C, Ambros PF, Hohenegger M (2010) Double impact on p-glycoprotein by statins enhances doxorubicin cytotoxicity in human neuroblastoma cells. Int J Cancer 126:20252035

15. Karagkounis G, DeVecchio J, Ferrandon S, Kalady MF (2018) Simvastatin enhances radiation sensitivity of colorectal cancer cells. Surg Endosc Other Interv Tech. Springer US 32:1533-1539

16. Lim T, Lee I, Kim J, Kang WK (2015) Synergistic effect of simvastatin plus radiation in gastric cancer and colorectal cancer: Implications of BIRC5 and connective tissue growth factor. Int $\mathbf{J}$ Radiat Oncol Biol Phys. Elsevier Inc. 93:316-325

17. Pathak R, Kumar VP, Hauer-Jensen M, Ghosh SP (2019) Enhanced survival in mice exposed to ionizing radiation by combination of gamma-Tocotrienol and simvastatin. Mil Med 184:644-651

18. Ostrau C, Hülsenbeck J, Herzog M, Schad A, Torzewski M, Lackner KJ, Fritz G (2009) Lovastatin attenuates ionizing radiation-induced normal tissue damage in vivo. Radiother Oncol. Elsevier Ireland Ltd 92:492-499

19. Nübel T, Damrot J, Roos WP, Kaina B, Fritz G (2006) Lovastatin protects human endothelial cells from killing by ionizing radiation without impairing induction and repair of DNA double-strand breaks. Clin Cancer Res 12:933-939

20. Ziegler V, Albers A, Fritz G (2016) Lovastatin protects keratinocytes from DNA damage-related pro-apoptotic stress responses stimulated by anticancer therapeutics. Biochim Biophys Acta, Mol Cell Res. Elsevier B.V. 1863:1082-1092 
21. Atil B, Berger-Sieczkowski E, Bardy J, Werner M, Hohenegger M (2016) In vitro and in vivo downregulation of the ATP binding cassette transporter B1 by the HMG-CoA reductase inhibitor simvastatin. Naunyn Schmiedeberg's Arch Pharmacol 389:17-32

22. Karlic H, Thaler R, Gerner C, Grunt T, Proestling K, Haider F et al (2015) Inhibition of the mevalonate pathway affects epigenetic regulation in cancer cells. Cancer Gene Ther. Elsevier Inc. 208:241252

23. Eke I, Cordes N (2011) Radiobiology goes 3D: how ECM and cell morphology impact on cell survival after irradiation. Radiother Oncol. Elsevier Ireland Ltd 99:271-278

24. Soule HD, Maloney TM, Wolman SR, Peterson WDJ, Brenz R, McGrath CM et al (1990) Isolation and characterization of a spontaneously immortalized human breast epithelial cell line, MCF-10. Cancer Res 50:6075-6086

25. Hehlgans S, Eke I, Deuse Y, Cordes N (2008) Integrin-linked kinase: dispensable for radiation survival of three-dimensionally cultured fibroblasts. Radiother Oncol 86:329-335

26. Seiwert TY, Salama JK, Vokes EE (2007) The concurrent chemoradiation paradigm-general principles. In: Nature clinical practice. Oncology 4 (2):86-100

27. Crosbie J, Magnussen M, Dornbier R, Iannone A, Steele TA (2013) Statins inhibit proliferation and cytotoxicity of a human leukemic natural killer cell line. Biomark Res 1:33

28. Crescencio ME, Rodríguez E, Páez A, Masso FA, Montaño LF, López-Marure R (2009) Statins inhibit the proliferation and induce cell death of human papilloma virus positive and negative cervical cancer cells. Int J Biomed Sci 5:411-420

29. Haviland JS, Owen JR, Dewar JA, Agrawal RK, Barrett J, BarrettLee PJ, Dobbs HJ, Hopwood P, Lawton PA, Magee BJ, Mills J, Simmons S, Sydenham MA, Venables K, Bliss JM, Yarnold JR, START Trialists' Group (2013) The UK standardisation of breast radiotherapy (START) trials of radiotherapy hypofractionation for treatment of early breast cancer: 10-year follow-up results of two randomised controlled trials. Lancet Oncol Elsevier Ltd 14:10861094

30. Whelan TJ, Pignol J-P, Levine MN, Julian JA, MacKenzie R, Parpia S, Shelley W, Grimard L, Bowen J, Lukka H, Perera F, Fyles A, Schneider K, Gulavita S, Freeman C (2010) Long-term results of Hypofractionated radiation therapy for breast Cancer. $\mathrm{N}$ Engl J Med 362:513-520

31. Chen Y-A, Shih H-W, Lin Y-C, Hsu H-Y, Wu T-F, Tsai C-H, Wu CL, Wu HY, Hsieh JT, Tang CH, Lai CH (2018) Simvastatin sensitizes Radioresistant prostate Cancer cells by compromising DNA double-Strand break repair. Front Pharmacol 9:600

32. Benham V, Bullard B, Dexheimer TS, Bernard MP, Neubig RR, Liby KT et al (2019) Identifying chemopreventive agents for obesity-associated cancers using an efficient, 3D high-throughput transformation assay. Sci Rep. Springer US 9:10278

33. Subik K, Lee J-F, Baxter L, Strzepek T, Costello D, Crowley P, Xing L, Hung MC, Bonfiglio T, Hicks DG, Tang P (2010) The expression patterns of ER, PR, HER2, CK5/6, EGFR, Ki-67 and AR by Immunohistochemical analysis in breast Cancer cell lines. Breast Cancer (Auckl) 4:35-41

34. Jung HH, Lee SH, Kim JY, Ahn JS, Park YH, Im YH (2016) Statins affect ETS1-overexpressing triple-negative breast cancer cells by restoring DUSP4 deficiency. Sci Rep. Nature Publishing Group 6:1-10

35. Lacerda L, Reddy JP, Liu D, Larson R, Li L, Masuda H, Brewer T, Debeb BG, Xu W, Hortobágyi GN, Buchholz TA, Ueno NT, Woodward WA (2014) Simvastatin Radiosensitizes differentiated and stem-like breast Cancer cell lines and is associated with improved local control in inflammatory breast Cancer patients treated with Postmastectomy radiation. Stem Cells Transl Med 3:849-856
36. Krause S, Maffini MV, Soto AM, Sonnenschein C (2008) A novel $3 \mathrm{D}$ in vitro culture model to study stromal-epithelial interactions in the mammary gland. Tissue Eng Part C Methods 14:261-271

37. Sowa MB, Chrisler WB, Zens KD, Ashjian EJ, Opresko LK (2010) Three-dimensional culture conditions lead to decreased radiation induced cytotoxicity in human mammary epithelial cells. Mutat Res. Elsevier B.V. 687:78-83

38. Acheva A, Aerts A, Rombouts C, Baatout S, Salomaa S (2014) Human 3-D tissue models in radiation biology : current status and future perspectives. Int J Radiat Res 12

39. Lo AT, Mori H, Mott J, Bissell MJ (2012) Constructing threedimensional models to study mammary gland branching morphogenesis and functional differentiation. J Mammary Gland Biol Neoplasia 17:103-110

40. Vidi P-A, Bissell MJ, Lelièvre SA (2013) Three-dimensional culture of human breast epithelial cells: the how and the why. Epithel Cell Cult Protoc 161-175

41. Inman JL, Bissell MJ (2010) Apical polarity in three-dimensional culture systems: where to now? J Biol 9:2

42. Longati $\mathrm{P}$, Jia X, Eimer J, Wagman A, Witt M-R, Rehnmark S, Verbeke C, Toftgård R, Löhr M, Heuchel RL (2013) 3D pancreatic carcinoma spheroids induce a matrix-rich, chemoresistant phenotype offering a better model for drug testing. BMC Cancer 13:95

43. Paškevičiūtè M, Petrikaite V (2017) Differences of statin activity in 2D and 3D pancreatic cancer cell cultures. Drug Des Devel Ther 11: 3273-3280

44. Kobayashi K, Baba K, Kambayashi S, Okuda M (2020) Effect of simvastatin on cell proliferation and Ras activation in canine tumour cells. Vet Comp Oncol. https://doi.org/10.1111/vco.12644

45. Sun FR, Wang SL, Wang M, Sun LM (2020) Simvastatin induces apoptosis of nasopharyngeal carcinoma cells through NF- $\mathrm{kB}$ signaling pathway. Eur Rev Med Pharmacol Sci 24(12):6726-6734

46. Alhakamy N, Fahmy UA, Ahmed OAA, Caruso G, Caraci F, Asfour HZ, et al. (2020) Chitosan coated microparticles enhance simvastatin colon targeting and pro-apoptotic activity. Marine Drugs 18(4). https://doi.org/10.3390/md18040226

47. Sánchez CA, Rodríguez E, Varela E, Zapata E, Páez A, Massó FA, et. al. Statin-induced inhibition of MCF-7 breast cancer cell proliferation is related to cell cycle arrest and apoptotic and necrotic cell death mediated by an enhanced oxidative stress. Cancer Investig 2008;26(7):698-707

48. Plesca D, Mazumder S, Almasan A (2008) Chapter 6 DNA Damage Response and Apoptosis. In: Programmed cell death, the biology and therapeutic implications of cell death, vols. 446. Methods in Enzymology, pp. 107-122, [R Khosravi-far, editor]. Amsterdam: Elsevier Acad. Press

49. Grdina DJ, Murley JS, Miller RC, Mauceri HJ, Sutton HG, Li JJ, Woloschak GE, Weichselbaum RR (2013) A survivin-associated adaptive response in radiation therapy. Cancer Res 73(14):4418 4428

50. Shin JS, Woo SH, Lee HC, Hong SW, Yoo DH, Hong S, Lee WJ, Lee MS, Jin YW, An S, Jin DH, Park IC (2010) Low doses of ionizing radiation suppress doxorubicin-induced senescence-like phenotypes by activation of ERK1/2 and suppression of p38 kinase in MCF7 human breast cancer cells. Int J Oncol 36(6):1445-1452

51. HNA K, Han NK, Hong MN, Chi SG, Lee YS, Kim T et al (2012) Analysis of the cellular stress response in MCF10A cells exposed to combined radio frequency radiation. J Radiat Res 53(2):176-183

Publisher's note Springer Nature remains neutral with regard to jurisdictional claims in published maps and institutional affiliations. 